\title{
SUATU PEMIKIRAN DALAM UPAYA PENINGKATAN EFEKTIVITAS PEN GENDALIAN MONETER DI INDONESIA
}

\section{Tarmiden Sitorus *)}

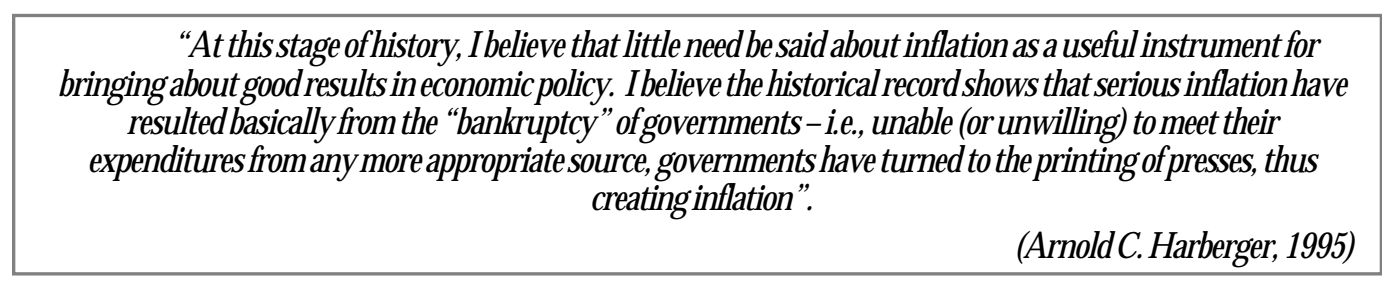

Pengendalian moneter tidak langsung dalam masa krisis moneter yang dialami oleh Indonesia saat ini menghadapi dilema. Di satu sisi, hubungan antara perubahan uang primer yang digunakan sebagai target operasional dengan perubahan variabel yang menjadi ultimatetargetkebijakan moneter relatif tidak stabi I. D i sisi lain, selain semakin sulitnyauntuk melakukan antisipasi faktor-faktor yang mempengaruhi perubahan uang primer, instrumen moneter yang tersediauntukmelakukan manuver juga sangat terbatas. Sistem perbankan yang tidaksehat dan kondisi pasar uang yang tersegmentasi menyebabkan tidak berfungsinya mekanismetransmisi secara efisien, sehingga sulit diharapkan suatu operasi pasar terbukayang efektif. $D$ an, dengan hanya mengandalkan SBI sebagai instrumen moneter, pencapaian sasaran ganda secaraserentakmerupakan pekerjaan yang sulit.

Faktor-faktor yang mempengaruhi perubahan uang primer bukan hanyaberasal dari faktor-faktor autonomous, tetapi juga berasal dari policy factors yang sebetulnya berada dalam kendali BankIndonesia, namun, BankIndonesia sepertinyatidak berdayauntuk mengaturnya secara lebih antisipatif. Faktor-faktor autonomous mencakup kondisi sektor keuangan yang semakin rentan terhadap gejolak baikdi dalam maupun di luar negeri. Disampingitu, transaksi keuangan Pemerintah yang fluktuatifikutmempengaruhi efektivitas pelaksanaan operasi moneter. Dari sisi policy factors, beberapafasilitas yang diberikan kepada bank-bank, seperti bantuan likuiditas Bank Indonesia (BLBI) yang berasal dari fasilitas overdraft yang diberikan kepada bank-bank, menambah ketidak pastian perubahan uang primer, yang padagilirannyamenyulitkan perencanaan moneter sehari-hari.

U paya peningkatan efktivitas pengendalian moneter dapat dilakukan melalui penyempurnaan dari berbagai sistem yang akan mengurangi ketidak pastian perubahan faktor-faktor yang mempengaruhi perubahan agregat moneter. Penerapan sistem nilai tukar crawling band dan pemberlakuan soft control terhadap pembelian devisaoleh bank-bank dari Bank Indonesia akan dapat mengurangi tekanan eksternal pada pergerakan nilai rupiah, sehingga pengendalian moneter sehari-hari dapat lebih diarahkan padasasaran internal. Selain itu, koordinasi yang lebih serasi antara Bank Indonesiadengan D epartemen Keuangan dalam hal pelaksanaan tran saksi keuangan pemerintah, pembatasan pemberian fasilitas overdraft melalui penerapan suatu aturan kegagalan setemen pembayaran antarbank, sertapengenalan obligasi Pemerintah sebagai alternatif instrumen moneter, diperlukan untuk dapat meningkatkan efisiensi dan efektivitas pelaksanaan operasi pasar terbuka.

*) Tarmiden Sitorus : Kepala Bagian, Biro Penelitian Intern, Urusan Penelitian dan Pengembangan Intern, Bank Indonesia 


\section{Pendahuluan}

mplementasi kebijaksanaan moneter di Indonesia dalam masa krisis saat ini dilematis. Banyaknya sasaran yang ingin dicapai secara serentak serta tidak berfungsinya mekanisme transmisi secara efisien akibat disintermediasi dalam sistem keuangan menyebabkan pengendalian moneter secara tidak langsung menjadi kurang efektif. Di satu sisi, perkembangan nilai tukar yang belum stabil dan inflasi yang masih tinggi memaksaBank Indonesia, sebagai otoritas moneter, untuk mempertahankan kebijakan uang ketat, yang berakibat tingginya suku bunga di dalam negeri. Di sisi lain, tingginya suku bunga telah berdampak negatif terhadap dunia usaha karena membengkaknya kewajiban pembayaran bunga dan terhentinya pemberian kredit baru oleh perbankan, akibatnya nonperforming loan meningkat dan bank-bank beroperasi dengan negativespread.

Meskipun demikian, baik IMF maupun Bank Dunia berpendapat bahwa, walaupun suku bunga sudah cukup tinggi, masih tingginya laju inflasi menyebabkan tingkat suku bunga riel saat ini sangat rendah bahkan mungkin negatif. ${ }^{1}$ Proposisi ini mempunyai implikasi bahwa dengan suku bunga riel yang negatif, para penabung akan terdorong untuk menarik uangnya dari bank dan membelanjakan pada barang atau menyimpannya dalam aset berharga. Kalau proposisi ini benar, suku bunga tinggi tampaknya masih perlu dipertahankan untuk sementara waktu, walaupun disadari hal ini akan mempersulitupaya pemulihan perekonomian yang sangat membutuhkan dana dari simpanan masyarakat, sementara sumber dana dari luar negeri sudah sangat terbatas.

Secaraesensi, terjadinya suku bunga tinggi merupakan konsekuensi logis dari ketatnya target pertumbuhan agregat moneter dalam rangka stabilitas nilai tukar dan inflasi. Yang menjadi pertanyaan, perlukah suku bunga sedemikian tinggi untuk memelihara target moneter yang ditentukan? Barangkali tidak, kalau pengendalian moneter dapat dilakukan lebih efisien dan efektif. A pabila, misalnya, gangguan terhadap nilai tukar dan inflasi dapat dikurangi melalui sistem pengendalian moneter yang lebih baik, maka tekanan pada suku bungatinggi akan berkurang.

Makalah ini menuangkan suatu hasil pemikiran mengenai upaya untuk meningkatkan efektivitas pengendalian moneter secara tidak langsung yang dapat diterapkan baik dalam masa krisis maupun pasca krisis. Pendekatan yang dilakukan adalah mengindentifikasi berbagai kendala yang dihadapi dalam wahana pelaksanaan pengendalian moneter seharihari dan menawarkan alternatif untuk mengatasi berbagai kendala tersebut. Alternatif

1 Proposisi ini masih menjadi bahan perdebatan, karena suku bunga riel ditentukan bukan oleh besarnya inflasi yang telah terjadi tetapi oleh expektasi inflasi di masa datang. Perdebatan adalah sekitar bagaimana mengukur ekspektasi inflasi yang, dalam prakteknya, tidak ada ukurannya yang baku. 
tersebut mencakup sistem nilai tukar dan devisa, koordinasi transaksi keuangan Pemerintah, pengaturan kegagalan setelmen untuk membatasi peranan Bank Indonesia sebagai "the lender of last resort", dan penerbitan obligasi Pemerintah sebagai instrumen moneter.

\section{Implementasi Pengendalian M oneter Saat Ini}

Dalam implementasi kebijakan moneter, bank sentral dapat melakukannya dalam dua cara, yaitu cara langsung dengan menggunakan otoritas yang dimiliki, atau cara tidak langsung dengan menggunakan kemampuan mempengaruhi pasar yang dimiliki berkaitan dengan kedudukan bank sentral sebagai "issuer" dari uang primer, atau sering disebut " "central bank money" (Mo). Dalam pengendalian moneter langsung, bank sentral menetapkan suatu "limit" terhadap kenaikan harga uang (suku bunga atau nilai tukar) atau kuantitas uang (kredit bank), sedangkan dalam pengendalian moneter tak langsung, bank sentral mempengaruhi kondisi permintaan dan penawaran melalui pasar uang. ${ }^{2}$ Pembahasan pada bagian berikut ini menguraikan secara singkat bagaimana cara pengendalian moneter yang dilakukan di Indonesia saat ini dan kendala apa saja yang sedang dihadapi dalam implementasinya.

\subsection{Kerangka Pengendalian M oneter}

Pengendalian moneter tidak langsung telah menjadi pilihan otoritas moneter di Indonesia sejak 1983, bersamaan dengan dihapusnyasistem “credit ceiling" dan pengaturan suku bunga, dan diperkenalkannya Sertifikat Bank Indonesia (SBI) dan Surat Berharga Pasar Uang (SBPU) sebagai instrumen pasar uang sekaligus sebagai instrumen pasar uang. Kerangka pengendalian moneter tidak langsung yang dilakukan saat ini secara singkat dapat dilihat pada Diagram-1. Dalam pengendalian moneter sehari-hari, otoritas moneter biasanya tidak mengaitkan langsung instrumen dengan sasaran akhir karena pengaruh dari tindakan moneter biasanya tidak seketika tetapi secara bertahap, dan adanya ketidak pastian antara pengaruh dari tindakan moneter terhadap pencapaian sasaran akhir. Otoritas moneter melakukan pendekatan sasaran antara yang juga berperan sebagai indikator. Dalam pelaksanaan pengendalian moneter tidak langsung, otoritas moneter selalu dihadapkan pada dua pilihan sasaran antara, apakah suku bunga atau agregat moneter. Pilihan tersebut dapat berubah-ubah sesuai dengan perubahan kondisi dan tantangan yang dihadapi. ${ }^{3}$

2 Diskusi lebih lanjut mengenai kelebihan dan kelemahan masing-masing alternatif pilihan ini dapat dilihat pada Alexander, Balino dan Enoch (1995), halaman 2-16.

3 Dalam sejarah pengendalian moneter di Indonesia, Bank Indonesia, dalam periode 1983-1987, memilih suku bunga sebagai target dengan alasan bahwa target agregat moneter pada saat terjadinya gelombang perubahan dalam sektor keuangan dan perubahan portofolio perbankan yang cukup berarti akan dapat menyebabkan gejolak suku bunga yang memberikan dampak negatif terhadap dunia usaha. Lihat IMF Occasional Paper Series No. 84, Section IV. 
Padatingkat operasional, biasanya otoritas moneter dapat menggunakan tingkat suku bunga jangka pendek ataupun uang primer, Mo, sebagai sasaran operasional yang dapat dipengaruhi secaralangsung oleh bank sentral melalui instrumen moneter. Dengan asumsi "money multiplier" yang stabil, perubahan pada uang primer ini diharapkan dapat menyentuh sasaran antara.

D iagram-1: Skema Pengendalian M oneter saat ini

\begin{tabular}{|l|l|l|l|}
\hline Instrumen & Sasaran Operasional & Sasaran Antara & Sasaran Akhir \\
\hline $\begin{array}{l}\text { Operasi Pasar Terbuka } \\
\text { (Lelang SBI) }\end{array}$ & $\begin{array}{l}\text { Base Money (Uang } \\
\text { primer) }\end{array}$ & Uang Beredar (M1 dan & Inflasi \\
& Net Domestic Assets & M2) & Pertumbuhan Ekonomi \\
& Net International Reserve & Neraca Pembayaran \\
\cline { 1 - 2 } Intervensi Valas & Nilai Tukar Rupiah & Nilai Tukar Rupiah & \\
\hline
\end{tabular}

Selain itu, mengingat peranan nilai tukar mata uang dalam negeri yang instrumental dalam aktifitassuatu perekonomian yang terbuka, bank sentral senantiasa berusaha, dalam batas kemampuannya yang tercermin pada jumlah cadangan devisa yang dimiliki, melakukan intervensi dalam pasar uang untuk stabilisasi pergerakan nilai tukar yang kondusif terhadap pencapaian sasaran akhir kebijakan moneter. Dengan sistem devisa bebas yang dianut Indonesia saat ini, pergerakan nilai tukar rupiah menjadi sangat sensitif terhadap gejolak-gejolak yang terjadi baik di dalam negeri maupun di luar negeri, sehingga tuntutan terhadap bank sentral untuk melakukan intervensi cukup tinggi. Namun, keterbatasan cadangan devisa yang dimiliki dibandingkan dengan tekanan pasar yang dihadapi tidak memungkinkan untuk melakukan intervensi secara aktif.

\subsection{Tantangan yang Dihadapi}

Pengendalian moneter dengan uang primer sebagai target operasional yang dilakukan oleh Bank Indonesia saat ini menghadapi dilema. Di satu sisi, hubungan antara uang primer dengan target moneter M 1 dan M 2 yang relatif kurang stabil, seperti tercermin pada money multiplier dapat menyebabkan pengaruh yang bersifat destabilizing. Di sisi lain, usahastabilisasi perubahan yang terjadi pada uang primer tidak mudah dilakukan karena beberapa alasan. Yang pertama, dalam kondisi di Indonesia saat ini, hanya sebagian kecil dari uang primer, yaitu cadangan bank-bank, yang dapat dipengaruhi oleh Bank Indonesia, sedangkan sebagian besar ( $70 \%$ dari Mo) adalah uang kartal yang perubahannya sepenuhnya 
dipengaruhi oleh dinamika pergerakan portofolio permintaan masyarakat. Yang kedua, adanya beberapa kebijakan Bank Indonesia (policy factors) yang mengurangi fleksibilitas operasi pengendalian moneter. ${ }^{4}$

Sementara itu, penetapan suku bunga sebagai sasaran antara juga dilematis. Bank Indonesia tidak dapat mengetahui dengan tepat tingkat bunga yang sesuai untuk mencapai sasaran akhir. Dengan kondisi pasar uang di dalam negeri yang tidak efisien akibat disintermediasi sektor keuangan, sulit diharapkan untuk memperoleh informasi yang lengkap dan akurat mengenai arah dan magnitude dari tingkat bunga yang tepat dan kondusif terhadap pencapaian sasaran akhir. Oleh karena itu, pilihan suku bunga sebagai sasaran antara akan dapat mengakibatkan kuantitas uang berfluktuasi dan pada gilirannya akan menyebabkan tingkat inflasi semakin tidak stabil. ${ }^{5}$

Dalam situasi yang serba tidak pasti diatas, dan memperhatikan adanya ancaman hiperinflasi di dalam negeri, Bank Indonesia, melalui kesepakatan dengan IMF, memilih agregat moneter sebagai sasaran antara, dengan uang primer sebagai sasaran operasional utama. Menyadari adanya berbagai kendala dalam pengendalian uang primer serta hubungan yang kurang stabil antara uang primer dengan sasaran antara, beberapa faktor yang mempengaruhi perubahan uang primer juga ditetapkan sebagai sasaran operasional, yaitu, net domestic assets dari Bank Indonesia, pemberian bantuan likuiditas kepada bankbank, dan net international reserves yang dikuasai oleh Bank Indonesia. Dengan monetary policy stanceyang cenderung masih ketat seperti tercermin pada target-targetkuantitas dalam kesepakatan dengan IMF, ruang yang tersedia untuk melakukan manuver saat ini tampaknya sangat kecil.

Secara teoritis, pengendalian moneter tidak langsung hanya bisa efektif kalau ada suatu pasar uang yang bekerja secara efisien dan untuk ini diperlukan suatu set institusi keuangan, dalam hal ini perbankan, sebagai pelaku pasar uang yang kompetitif sehingga mekanismetransmisi dari instrumen moneter kesasaran moneter yang ingin dicapai dapat berfungsi secara optimal. ${ }^{6}$ Dalam pelaksanaan pengendalian moneter tidak langsung yang dimulai sejak tahun 1983 di Indonesia, prekondisi diatas sebenarnya belum dimiliki. Kalau begitu kenapa Bank Indonesia dengan sadar menerapkan suatu sistem yang baru tanpa

4 Diskusi lebih lanjut mengenai hal ini, lihat Boediono (1998).

5 Sarwono dan Warjiyo (1998) mengusulkan pendekatan harga sebagai target dengan menggunakan indikator kebijakan moneter (IKM) yang mencerminkan pengaruh suku bunga dan "real effective exchange rate (REER)" terhadap permintaan agregat nyata.

6 Sistem keuangan yang efisien akan menghasilkan biaya intermediasi dan marjin pinjaman (lending margin) yang rendah, penyerahan dana yang tinggi dan alokasi kredit yang efisien. Diskusi lebih lanjut mengenai hal ini, lihat Tseng \& Corker (1991) 
dukungan prekondisi yang dibutuhkan? Ada premis waktu itu yang mengatakan bahwa sistem pengendalian moneter langsung telah menyebabkan berbagai distorsi dalam al okasi dana yang sifatnya fundamental, sehingga sistem tersebut harus segera ditinggalkan. Penerapan sistem pengendalian moneter tidak langsung dapat segera dijalankan sementara pasar uang dibenahi. Itu yang dilakukan selama ini. Namun, setelah 15 tahun, pasar uang yang didambakan semakin jauh dari real ita karena institusi pelaku yaitu sistem perbankan masih segmented dan tidak kompetitif. Dengan krisis ekonomi dan moneter yang dihadapi saat ini, kondisi institusi perbankan semakin parah, dan dibutuhkan waktu yang lama dan biaya yang cukup besar untuk merestrukturisasinya. Walaupun demikian, kondisi ini tampaknya tidak dapat menjadi al asan untuk kembali kerejim pengendalian moneter secara langsung. Pilihannya, institusi perbankan dan pasarnya yang harus dibenahi sesegera mungkin, dan sementara ini belum tuntas, otoritas moneter tidak boleh terlalu berharap untuk melakukan pengendalian moneter secara optimal.

\section{Identifikasi Berbagai Kendala Dalam Pengendalian Moneter}

Dalam pengendalian moneter tidak langsung, uang primer, Mo dan, lebih spesifik lagi, cadangan bank-bank baik (baik yang ada pada bank sentral maupun yang disimpan pada bank-bank) memegang peranan sentral karena semuatransaksi yang berkaitan dengan operasi pengendalian moneter terekam dalam variabel moneter ini. Oleh karenaitu, efektif tidaknya pengendalian moneter bukan hanya tergantung pada terdapatnya instrumen yang memadai tetapi juga pada sejauh mana bank sentral mampu mengatasi kendala-kendala yang ada dan memprediksi perubahan-perubahan berbagai faktor yang mempengaruhi Mo. Sementara efektivitas pengendalian nilai tukar sangat tergantung pada posisi cadangan devisa yang dimiliki dan adanya pasar uang antarbank yang efisien.

Tabel 1: Faktor-faktor yang mempengaruhi uang primer (pertumbuhan tahunan, \%)

\begin{tabular}{|c|c|c|c|c|c|c|c|c|}
\hline & \multirow{2}{*}{1994} & \multirow{2}{*}{1995} & \multirow{2}{*}{1996} & \multirow{2}{*}{1997} & \multicolumn{4}{|c|}{1998} \\
\hline & & & & & Jan. & April & Juli & Agus. \\
\hline Net International Reserve 1) & -3.9 & 13.9 & 40.2 & 106.8 & 63.3 & 51.1 & -21.1 & -22.1 \\
\hline Net Domestic Assets & -28.7 & 10.0 & 49.0 & 259.5 & 113.5 & 104.2 & -50.0 & -51.3 \\
\hline Tagihan pada Pemerintah bersih & 40.4 & 65.2 & 8.2 & 75.2 & 130.0 & 30.4 & 104.5 & 72.9 \\
\hline Bantuan Likuiditas (BLBI) & 120.6 & 53.8 & -23.3 & 660.8 & 973.0 & 1228. & 1554 & 1126 \\
\hline Kredit Likuiditas (KLBI) & -3.61 & -2.16 & 29.8 & 11.7 & 42.7 & 109.2 & 30.5 & 21.4 \\
\hline Tagihan lainnya & -12.7 & 70.4 & -4.3 & -0.3 & -0.8 & 9.3 & 9.0 & 13.0 \\
\hline Operasi Pasar Terbuka & -35.8 & -22.0 & 63.5 & -14.0 & -17.8 & 162.0 & 365.8 & 286.6 \\
\hline Uang primer & 25.8 & 16.7 & 34.5 & 34.3 & 62.6 & 57.2 & 75.9 & 69.5 \\
\hline M1 & 23.3 & 16.1 & 21.7 & 22.2 & 40.9 & 47.7 & 52.8 & 60.3 \\
\hline M2 & 20.2 & 27.6 & 29.6 & 23.2 & 55.0 & 52.5 & 75.3 & 66.0 \\
\hline
\end{tabular}




\subsection{Faktor-Faktor Yang Mempengaruhi Sasaran 0 perasional}

Sebagaimana terlihat pada Tabel-1, perubahan-perubahan dalam uang primer dipengaruhi oleh beberapa faktor yang semuanya tercatat pada neraca otoritas moneter. Faktor tersebut dapat dikelompokkan dalam faktor eksternal dan faktor internal. Faktor eksternal mencerminkan kondisi eksternal sektor keuangan yang terekam pada pos aktiva luar negeri bersih (net foreign assets, NFA), sedangkan faktor internal mencerminkan perubahan-perubahan pada faktor-faktor yang mempengaruhi kondisi likuiditas di dalam negeri. Faktor internal ini tercermin pada "net domestic asset" dalam neracaotoritas moneter, yang meliputi transaksi keuangan Pemerintah (net claims on government, NCG) dan transaksi antara Bank Indonesia dengan bank-bank, antara lain, dalam rangka pemberian bantuan likuiditas (BLBI), kreditlikuiditas (KLBI) dan operasi pasar terbuka.

Dilihat dari segi karakteristiknya, kedua faktor NFA dan NCG bersifat "autonomous" dalam pelaksanaan pengendalian moneter, artinya perubahan-perubahan dalam faktor tersebut sepenuhnya di luar kontrol otoritas moneter, sehingga faktor-faktor lain yang berada dalam kontrol otoritas moneter atau yang disebut sebagai "policy factor" harus menyesuaikan diri melalui operasi moneter untuk mencapai sasaran operasional yang dikehendaki.

\subsection{Faktor Eksternal}

Pada periode sebelum krisis, kendala paling besar dalam pengendalian moneter di Indonesia adalah pesatnya aliran dana masuk khususnya sejak tahun 1995. Aliran dana masuk yang cukup pesat tersebut, di satu sisi, memperkuat neraca pembayaran dengan akumulasi cadangan devisa, di sisi lain, menyebabkan sektor keuangan eksternal Indonesia semakin rentan (vulnerable) terhadap setiap gejolak (shock) baik yang terjadi di dalam negeri maupun di luar negeri. Selain itu, dengan sistem devisa bebas dan sistem pengendalian nilai tukar mengambang terkendali (managed floating) yang dilakukan, fluktuasi dalam faktor NFA semakin tinggi dan sulit diprediksi, sehingga mempersulit perencanaan moneter sehari-hari.

Surplus neraca pembayaran yang berkelanjutan sebagai hasil dari pesatnya aliran dana masuk kedalam negeri telah menjadikan posisi nilai tukar rupiah cenderung menguat.7 Seperti terlihat pada Grafik-4(Lampiran), dengan sistem nilai tukar yang menerapkan sistem band, adanya kecenderungan nilai tukar rupiah yang menguat tersebut tercermin pada pergerakan kurs sehari-hari yang berada sekitar "Iower band" khususnya setahun terakhir sebelum krisis. Pada periode tersebut, tindakan intervensi pasar valuta asing untuk mempertahankan nilai tukar rupiah jarang dilakukan oleh Bank Indonesia.

7 Pemerintah telah memanfaatkan surplus tersebut untuk melakukan pembayaran lebih cepat (sebelum jatuh waktu) sebagian kewajiban angsuran pinjaman luar negerinya khususnya yang berasal dari lembaga internasional. 
Pada awal krisis dimulai, tekanan terhadap nilai tukar rupiah mulai terlihat pada pergerakan kurs yang berpindah ke sekitar dan bahkan sering menyentuh batas atas dari band, sehingga memaksa Bank Indonesia melakukan tiga kali pelebaran band. Ternyata kemudian, sistem band tersebut dinilai tidak dapat lagi dipertahankan, mengingat tekanan aliran dana keluar yang semakin meningkat dan cadangan devisa yang semakin mengecil. Sejak bulan A gustus 1997, sistem nilai tukar di Indonesia memasuki era baru, yaitu sistem mengambang penuh (free floating). Pertanyaannya sekarang, apakah sistem yang baru ini cukup memadai untuk mendukung upaya stabilisasi moneter? Dari data empiris selama setahun terakhir (lihat Grafik 1 dan Grafik 3 pada Lampiran), penerapan sistem nilai tukar mengambang penuh, dengan mempertahankan sistem devisa bebas, menunjukkan kinerja yang tidak memuaskan, seperti tercermin pada pergerakan nilai tukar rupiah yang tidak menentu (volatile) dan inflasi yang meningkat tajam. ${ }^{8}$

Secara teori, dengan rejim devisa bebas dan sistem nilai tukar mengambang penuh, dampak moneter dari NFA akan selal u netral apabila terdapat pasar uang yang bekerja secara efisien, sehingga kebijakan pengendalian moneter dapat lebih diarahkan pada sasaran moneter internal. Dengan demikian, pengendalian moneter dengan uang primer sebagai target operasional akan menjadi lebih efektif. Namun, adanya sasaran lain yang tidak kurang pentingnya, yaitu stabilitasnilai tukar, menjadikan hal tersebutmenjadi kurang relevan. Sesuai hukum permintaan dan penawaran, nilai tukar akan terbentuk padatitik keseimbangan antara kedua agregat tersebut pada pasar valuta asing. A pabila terjadi ketidak seimbangan pasar karena pergeseran salah satu atau kedua agregat tersebut, maka nilai tukar akan bergerak secara alamiah menuju titik keseimbangan baru, sehingga tidak akan terjadi ekses permintaan ataupun ekses penawaran yang mempunyai dampak moneter. Mekanisme tersebut akan terjadi secara optimal kalau didukung oleh suatu prekondisi pasar uang yang kompetitif. Namun, kenyataannya tidaklah selalu demikian, karena pasar uang yang benar-benar kompetitif itu ternyata sulit diperoleh, bahkan barangkali hanya merupakan suatu "utopia". 9

Di Indonesia, prekondisi pasar uang yang efisien masih jauh dari harapan. Pelaku pasar yang umumnya adalah dunia perbankan masih segmented dan instrumen yang digunakan masi h relatif terbatas, demikian pula volumeyang diperdagangkan masih relatif kecil. Selain itu, sejumlah transaksi untuk kepentingan Pemerintah atau lembaga-lembaga

8 Tentu, kinerja dari sistem nilai tukar mengambang dengan rejim devisa bebas ini tergantung pada dukungan berbagai faktor ekonomi lainnya serta faktor non-ekonomi yang ikut mempengaruhi sentimen pasar.

9 Berbagai studi empiris yang dilakukan belakangan ini menyatakan bahwa "hipotesa pasar yang efisien" tidak didukung oleh bukti empiris yang memadai. Selain faktor permintaan dan penawaran, ada faktor "psikologis" yang mempengaruhi pergerakan nilai tukar. Namun, proposisi tersebut tidak mengandung arti bahwa pasar yang efisien tidak diperlukan untuk mengurangi fluktuasi nilai tukar. Pasar yang efisien merupakan "necessary" tetapi bukan "sufficient". Proposisi ini merupakan dalih kenapa bank sentral perlu campur tangan dalam pasar. (Lihat Bob Rankin, 1998, halaman 10) 
negara dilakukan di luar pasar valuta asing, yaitu secara langsung dikelola oleh Bank Indonesia. Dengan absennya suatu prekondisi yang ideal, pergerakan nilai tukar yang stabil dan optimal akan sulit diperoleh. Sistem nilai tukar mengambang yang dianut sampai saat ini, pada hakekatnya, lebih mencerminkan ketidak berdayaan otoritas moneter untuk melakukan stabilisasi pergerakan nilai tukar dari pada sebagai suatu pilihan yang optimal. Kalau sistem devisa bebas masi dipertahankan seperti sekarang ini, pergerakan nilai tukar rupiah akan sangat rentan terhadap gejolak-gejolak yang terjadi baik di dal am negeri maupun di luar negeri. Perkembangan selama ini telah membuktikan hal tersebut. Bagaimanapun, dalam upaya pemulihan perekonomian yang sedang mengal ami stagnasi diperlukan adanya stabilitas dalam pergerakan nilai tukar untuk memberikan kepastian dalam kegiatan investasi maupun kegiatan perekonomian yang sangat terkait dengan perdagangan luar negeri.

Dari berbagai uraian diatas, dapat disimpulkan bahwa sistem pengendalian nilai tukar mengambang penuh yang dianut saat ini sulit diharapkan untuk bisa sustainable dalam mencapai sasaran-sasaran moneter baik eksternal maupun internal. Oleh karenaitu, diperlukan suatu sistem pengendalian nilai tukar dan sistem devisa yang tepat tanpa harus mengorbankan sasaran-saran moneter lainnya seperti cadangan devisa dan inflasi, serta sasaran program penyehatan sistem perbankan nasional.

\subsection{Faktor Internal}

Sebagaimana telah dijelaskan dimuka, faktor internal mencakup dua hal, yaitu, transaksi keuangan Pemerintah dan policy factors yang tercermin padatransaksi antaraBank Indonesiadengan bank-bank yang mempengaruhi perubahan posisi rekening giro bank-bank pada Bank Indonesia.

Transaksi keuangan Pemerintah meliputi pelaksanaan APBN (Anggaran Penerimaan dan Belanja Negara), dan transaksi keuangan yang dilakukan oleh badanbadan usaha milik negara (BUMN) atas instruksi Pemerintah. Data empiris menunjukkan bahwa fluktuasi transaksi keuangan Pemerintah memberikan dampak moneter yang cukup berarti. Dalam hal yang berkaitan dengan pelaksanaan APBN, adanya dampak moneter tersebut berkaitan erat dengan fungsi Bank Indonesia sebagai pemegang kas Pemerintah, sehingga setiap gap yang bersifat sementara antara penerimaan dan pengeluaran Pemerintah secara otomatis ditalangi oleh Bank Indonesia. ${ }^{10}$ Dampak moneter ini tercermin pada perubahan posisi tagihan Bank Indonesia kepada Pemerintah (NCG). Perubahan yang terjadi pada faktor NCG sering menjadi kendala dalam pengendalian moneter sehari-hari karena adanya ketidak pastian yang tinggi bahkan sering memberikan gejolak pada perkembangan

10 Dengan absennya surat hutang Pemerintah dalam pasar uang dalam negeri, pembatasan pinjaman atau uang muka dari bank sentral akan dapat menghambat pelaksanaan anggaran Pemerintah ( Diskusi lebih lanjut mengenai hal ini, lihat Cottarelli 1993, hal 12-13) 
pasar uang. Walaupun APBN tahun-tahun sebel um krisis selalu ditargetkan berimbang yang berarti dampak moneter dari transaksi Pemerintah secara tahunan akan netral, realisasi pelaksanaan A PBN tidak selalu seimbang, dan transaksi yang dilakukan Pemerintah seharihari memberikan fluktuasi yang cukup berarti pada faktor NCG yang selama ini sulit diprediksi (lihat Grafik-2 pada Lampiran). A palagi dengan ABPN tahun 1998/ 99 yang ditargetkan akan mengalami defisit yang sangat besar, yaitu 6.0 persen dari PDB, akan menambah beban yang lebih berat bagi upaya stabilisasi moneter.

Selain itu, transaksi keuangan yang dilakukan oleh sejumlah Lembaga Negara dan BUMN atas instruksi Menteri Keuangan, sebagai pemilik, sering menimbulkan gejolak moneter yang cukup berarti. Pengalihan deposito milik sejumlah BUMN keSertifikat Bank Indonesia (SBI) dalam jumlah besar dan secara tiba-tiba pada masa lalu, misalnya, bukan hanya menimbulkan gejolak moneter tetapi juga telah mengakibatkan sejumlah bank mengalami kesulitan likuiditas yang cukup serius. Kesulitan likuiditas ini, pada gilirannya, memaksa Bank Indonesia menyediakan bantuan likuiditas kepada bank-bank. Oleh karena itu, untuk mengurangi gejolak dan beban moneter dari pelaksanaan transaksi keuangan Pemerintah dan juga Lembaga dan BUMN diperlukan suatu koordinasi yang baik antara Bank Indonesia sebagai otoritas moneter dan Departemen Keuangan sebagai otoritasfiskal.

Policy factors dapat dibagi dalam dua kelompok, yaitu pinjaman bank-bank dari Bank Indonesia (net credits to commercial banks, NCB), dan intervensi pasar uang, baik dalam pasar valuta asing maupun dalam pasar rupiah melalui operasi pasar terbuka dengan menggunakan instrumen SBI dan SBPU. Berbagai fasilitas yang mempengaruhi pinjaman bank-bank dari Bank Indonesia yang mencakup kredit likuiditas Bank Indonesia (KLBI), bantuan likuiditas Bank Indonesia (BLBI) dan kredit-kredit khusus pada hakekatnya merupakan distorsi terhadap prinsip pengendalian moneter secara tidak langsung yang menyerahkan al okasi dana pada mekanisme pasar yang dianggap paling efisien.

Pemberian kreditlikuiditas (KLBI) bukan merupakan hal baru dalam sistem moneter di Indonesia. Dengan menyadari distorsi yang disebabkannya, Pemerintah melalui Pakto 1988, telah memberikan komitmen untuk secara bertahap menurunkan peranan dari kredit likuiditastersebut. Dari sejak tahun 1990 sampai dengan 1995, kreditlikuiditasterusmengalami kontraksi sehingga membantu mengurangi beban kontraksi yang harus dilakukan melalui operasi pasar terbuka. A kan tetapi, seperti terlihat pada Tabel-1, pemberian kreditlikuiditas ini kembali mengalami ekspansi yang cukup besar sejak tahun 1996 sejalan dengan adanya kebijakan Pemerintah untuk membiayai kegiatan tertentu. Dengan terjadinya krisis seperti sekarang ini, tekanan untuk melakukan ekspansi kredit likuiditasBank Indonesia dimaksud semakin besar untuk mendukung program-program Pemerintah dalam pemberdayaan golongan masyarakat lemah dan mendorong dunia usaha yang berorientasi ekspor. 
Perubahan pinjaman bank-bank menjadi lebih sulit diprakirakan karena adanya fasilitas BLBI yang diberikan melalui mekanisme "overdraft" dalam sistem kliring dan setelmen pembayaran antarbank. ${ }^{11}$ Dalam prakteknya, pemberian fasilitas tersebut khususnya sejak krisis terjadi nyaristanpa batas dan bahkan tanpa jaminan yang semestinya. A kibatnya, meskipun fasilitas tersebut merupakan suatu policy factor yang berada dalam batas kendali Bank Indonesia, dampaknya terhadap pengendalian moneter sehari-hari lebih bersifat "autonomous".

Sebenarnya, pemberian fasilitas BLBI ini telah dilakukan jauh sebelum krisisterjadi, dengan maksud untuk membantu program penyehatan beberapa bank bermasalah. $N$ amun, dengan semakin beratnya permasalahan yang dihadapi bank-bank sejak terjadi krisis, yang diikuti dengan hilangnya kepercayaan masyarakat terhadap perbankan nasional, pemberian fasilitas BLBI melalui mekanisme overdraft (saldo debet) meningkat dengan sangat pesat (Grafik-1). Data bulan Agustus 1998 menunjukkan bahwa jumlah BLBI tercatat sebesar Rp 178triliun, jauh diatas posisi uang primer yang hanya sebesar Rp 71 triliun. Disadari bahwa, di satu sisi, pemberian fasilitas tersebut telah memberikan jaminan kelancaran dalam sistem pembayaran nasional karena semua resiko kegagalan setelmen diambil alih oleh Bank Indonesia, akan tetapi, di sisi lain, dampak negatifnyasudah terasa. Fasilitasjaminan tersebut bukan hanya menjadi kendala yang cukup berarti dalam operasi pengendalian moneter, tetapi jugatelah menimbulkan moral hazard di kalangan perbankan. Peranan Bank Indonesiasebagai the lender of last resort semakin kabur atau tidak ada batasannya, dan menjadi dilematis. Di satu sisi, kalau fasil itas ini dihentikan akan dapat berakibat semakin banyak bank yang harus tutup yang dikhawatirkan akan lebih meningkatkan ketidak percayaan masyarakatterhadap perbankan nasional. Di sisi lain, bila fasilitas ini diteruskan dengan persyaratan yang sangat longgar seperti selama ini, pada gilirannya, akan menyulitkan upaya restrukturisasi bankbank dan mendidik masyarakat menjadi tidak peduli terhadap adanya resiko yang berbedabeda padasetiap bank. Peranan disiplin pasar (market discipline) untuk mendidik bank-bank dan masyarakat dalam mengelola resiko menjadi tidak jalan.

Pemberian BLBI yang nyaris tanpa batas tersebut tampaknyasulit dihentikan selama masih adanyajaminan Pemerintah yang sangat luas (sering disebut sebagai blanket gurantee) terhadap seluruh kewajiban bank dan jaminan dimuka yang bersifat tunai (cash collateral)

11 Pemberian fasilitas overdraft kepada bank-bank yang mengalami kesulitan likuiditas sementara merupakan hal yang lazim dilakukan oleh berbagai bank sentral. Hal ini berkaitan dengan pelaksanaan fungsi bank sentral sebagai the lender of last resort. Namun, menyadari dampak "moral hazard" yang mungkin timbul, fasilitas ini biasanya diberikan dengan aturan yang ekstra ketat, seperti batasan jumlah yang dapat diberikan dan adanya jaminan yang memadai dalam bentuk surat berharga. Di Jepang, misalnya, pemberian fasilitas tersebut dilakukan secara ketat, bahkan harus ada "personal guarantee" dari pemilik dan pengurus. (Lihat Bank of Japan: Functions of and Risks in Payment and Settlement Systems in Japan, Special Paper No..216, June 1992, halaman 29). Di Indonesia, walaupun fungsi Bank Indonesia sebagai "the lender of last resort" didukung oleh Undang-Undang Bank Sentral No 13 tahun 1968, tidak ada batasan dan kriteria yang jelas dalam pelaksanaannya. 


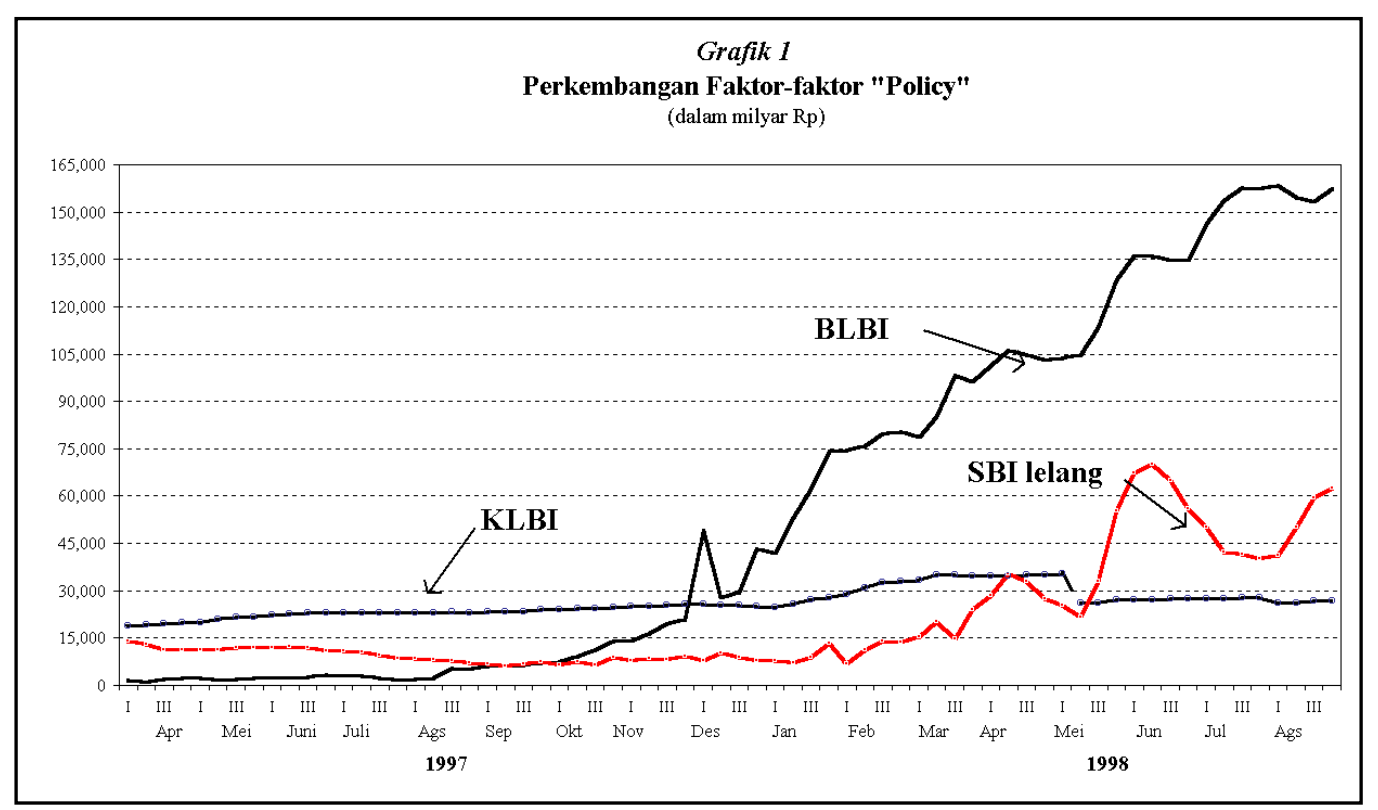

untuk menjamin L/ C. Pada hakekatnya, pemberian fasilitas overdraft yang sangat longgar saat ini merupakan solusi yang bersifat "ex-ante" dalam pelaksanaan mekanismepenjaminan untuk menghindari atau mengurangi beban administratif yang diperlukan. $\mathrm{Hal}$ ini sebetulnya kurang sejalan dengan prinsip penjaminan yang bersifat ex-post, artinya jaminan direalisir apabila telah terjadi default secara permanen oleh pihak tertagih. Realisasi jaminan terhadap pemilik simpanan atau kreditur yang memberikan pinjaman kepada bank semestinya hanya akan dilakukan setelah bank tersebutbenar-benar tidak mampu lagi memenuhi kewajibannya. A pabila prinsip ini dipegang, mestinya tersediaruang untuk memperketat pemberian fasilitas overdraft kepada bank-bank tanpa harus mengorbankan tingkat kepercayaan masyarakat terhadap perbankan nasional. Hal ini dapat dilakukan dengan penerapan suatu pengaturan kegagal an setelmen antarbank diantara para pesertakliring. Prinsipnya adalah bahwa resiko kegagalan setelmen adalah merupakan tanggung jawab setiap pesertakliring, artinyasetelmen antarbank sedapat mungkin harus squaring antara sesama peserta, sehingga peranan Bank Indonesia sebagai the lender of last resort menjadi seminimal mungkin. ${ }^{12}$ Pada gilirannya,

12 Prinsip ini telah dituangkan dalam "blue print" sistem pembayaran nasional. Dikatakan bahwa "pihak yang ikut serta dalam mekanisme pengaturan transfer dana antarbank dimana mereka memperoleh manfaat atasnya, harus ikut menaggung biaya dan resiko yang timbul" (White Paper, halaman 26). Dalam sebuah artikel IMF disebutkan bahwa "Secara teori, bank sentral dapat memberikan jaminan agar setelmen dapat dilaksanakan, namun hal ini dapat menimbulkan moral hazard. Jaminan seperti ini akan mengurangi insentif bagi peserta untuk mengelola resiko mereka sendiri dan akan mengganggu implementasi kebijakan moneter...." (Lihat Hook 1995, halaman 27). 
transaksi antarbank yang selalu "squaring" bukan hanya akan mengurangi ketidakpastian pada perubahan-perubahan uang primer sebagai target operasional pengendalian moneter, tetapi juga meningkatkan peranan disiplin pasar dalam mendorong profesionalismebankbank dalam pengelolaan likuiditas.

Selain berbagai fasilitas diatas, faktor lain yang juga ikut mempengaruhi efektivitas pengendalian moneter adalah adanya "floating" dalam sistem pembayaran antar-bank dan praktek "round-tripping" untuk menghindari ketentuan di bidang likuiditas bank seperti cadangan wajib minimum dan "net open position" dalam valuta asing. Adanya faktorfaktor ini menjadikan informasi mengenai posisi cadangan bank-bank secarareal timetidak diperoleh, sehingga pengendalian moneter sehari-hari melalui operasi pasar terbuka sulit dilakukan secara akurat. Artinya kemungkinan terjadinya "overshooting" atau "undershooting" menjadi lebih besar yang dapat mengakibatkan "destabilizing" terhadap perkembangan pasar. Oleh karena itu, baik "float" maupun "round tripping" perlu diminimaliser, kalau tidak bisa dieliminir, untuk mendukung efektifnya operasi pasar terbuka. Hal ini dapat dilakukan melalui penyempurnaan sistem kliring dan percepatan setelmen antarbank.

\subsection{Instrumen Moneter}

Penggunaan SBI, yang merupakan surat hutang Bank Indonesia, sebagai instrumen moneter, dalam kondisi perbankan yang parah saat ini, tidak efisien dan tidak fleksibel. Dikatakan tidak efisien karena biaya bunga yang cukup besar yang harus ditanggung oleh Bank Indonesia, sementara, dengan target kuantitas yang ditetapkan, tingkat bunga yang terjadi sampai derajat tertentu ditentukan oleh kekuatan pasar uang yang didominasi oleh sekelompok kecil bank pelaku. Dikatakan tidak fleksibel karena pada saat jatuh tempo, pembayaran kembali SBI yang dimiliki bank-bank oleh Bank Indonesia yang secara otomatis merupakan ekspansi moneter yang mengembalikan kondisi likuiditas bank-bank pada posisi semula. Operasi SBI yang dilakukan selama ini cenderung satu arah (one-sided), yaitu, kontraksi bukan untuk injeksi likuiditas. ${ }^{13}$ Oleh karena itu, ceteris paribus, untuk tetap mempertahankan keketatan likuiditasyang diharapkan, diperlukan operasi lelang SBI secara terus menerus. Dengan oustanding SBI yang semakin membengkak yang disertai dengan besarnya BLBI, sebagaimana dijelaskan pada bagian terdahulu, Bank Indonesia praktis melakukan operasi pasar terhadap uangnya sendiri. Dengan hanya mengandalkan SBI

13 Sebetulnya, operasi SBI dari dua arah (double-sided) bisa dilakukan dengan lebih mengaktifkan pembelian SBI oleh Bank Indonesia sebelum jatuh tempo, atau "repo" dengan inisiatif baik dari bank-bank maupun dari Bank Indonesia. 
sebagai instrumen dalam operasi pasar terbuka, biaya kontraksi moneter yang dilakukan menjadi sangat mahal. ${ }^{14}$

Sebetulnya surat berharga pasar uang (SBPU) merupakan instrumen yang relatif fleksibel karena inisiatif untuk melakukan transaksi ada di tangan Bank Indonesia dan biaya bunga yang timbul menjadi beban bank-bank. Akan tetapi, dalam situasi perbankan yang cukup parah dan dunia usaha yang mengalami stagnasi saat ini, penggunaan istrumen hutang ini oleh pelaku pasar sangat sedikit, kal aupun ada. Disamping itu, tindakan kontraksi moneter melalui SBI yang masihterus dilakukan secara agresif, menyebabkan alternatif ini tidak berkembang.

Selain lelang SBI, untuk mengendal ikan likuiditasrupiah di pasar uang, Bank Indonesia juga melakukan intervensi (pinjam meminjam) secara bilateral dengan bank-bank dengan jangka waktu sampai dengan satu minggu. Cara intervensi seperti ini jelas mempunyai kelemahan. Walaupun, di satu sisi, kelihatannya cukup efektif untuk dapat mencapai target uang primer harian, di sisi lain, likuiditas bank-bank yang disedot yang jangka waktunya umumnya overnight tidak akan banyak mempengaruhi potensinya untuk menciptakan uang giral ataupun uang beredar M 1 atau M2, yang menjadi "intermediate target" dari kebijakan moneter. Likuiditasyang disedot tersebut pada hakekatnyatidak lebih dari pada dana "idle" yang sifatnya sangat temporer dan tidak banyak mempengaruhi komitmen bank-bank dalam melakukan transaksi, tetapi dengan murah hati Bank Indonesia bersedia memberikan bunga yang cukup menarik. Kalau demikian halnya, patut dipertanyakan apakah intervensi bilateral seperti ini merupakan instrumen moneter atau hanya sebagai instrumen subsidi.

\section{Usulan Penyempurnaan Pengendalian Moneter}

Usulan berikut ini mencakup upaya-upaya untuk mengatasi berbagai kendalayang telah dibahas dimuka, baik yang berkaitan dengan faktor eksternal maupun internal. Cakupan usulan meliputi pembenahan sistem yang berkaitan atau yang memberikan dampak terhadap faktor-faktor yang mempengaruhi perubahan sasaran moneter, dan instrumen yang digunakan untuk melakukan operasi pasar terbuka.

\footnotetext{
14 Data bulan Agustus 1998 terakhir menunjukkan, dengan suku bunga tinggi saat ini (SBI 70 persen), untuk menyedot likuditas sebesar Rp20 trilion Bank Indonesia harus mampu menjual SBI sebesar Rp70 triliun dan dana yang diperoleh secara otomatis dikembalikan kembali kepada bank-bank dalam bentuk biaya bunga yang jumlahnya sekitar Rp50 trilion. Apabila Bank Indonesia harus melakukan sterilisasi BLBI yang jumlahnya telah mencapai Rp 180 trilion, maka diperlukan lelang SBI sebesar Rp600 trilion dan beban bunga yang harus ditanggung sebesar Rp420 trilion. Hal ini tidak mungkin dilakukan, karena biaya yang harus dikeluarkan harus ada batasnya. Kalau tidak, Bank Indonesia sebagai bank sentral akan bangkrut. Menyadari resiko seperti ini, penggunaan surat hutang bank sentra di sejumlah negara dilakukan secara terbatas. Di Malaysia dan Thailand, misalnya, penggunaan instrumen ini hanya bersifat "ad hoc" untuk mendukung instrumen lainnya. Di Philippine, surat hutang bank sentral digunakan secara aktif bersama-sama dengan surat hutang Pemerintah. Diskusi lebih lanjut, lihat Carling (1994).
} 


\subsection{Sistem Nilai Tukar "Crawling Band"}

Sistem nilai tukar "crawling band" yang diusulkan disini merupakan variasi dari sistem nilai tukar mengambang terkendali yang dianut pada masa sebelum krisis. Kalau dalam periodesebelum krisis, pergerakan nilai tukar ditargetkan bergerak pada suatu kisaran atau yang disebut "band" (dengan batas bawah dan batas atas) yang perubahannya jarang dilakukan, ${ }^{15}$ dalam sistem "crawling band" ini, band akan bergerak secara perlahan-lahan (crawl). A pabila pergerakan kurs mendekati atau menyentuh batas atas, Bank Indonesia melakukan intervensi untuk mengembalikan kurs kedalam band. Pada sistem "crawling band" ini, yang ditentukan sebagai target adalah lebar band-nya, sementara batas bawah dan batas atas akan disesuaikan secara periodik dengan kekuatan pasar yang terjadi, sehingga pergerakan nilai tukar masih dapat berfluktuasi asalkan dalam band yang ditetapkan. Bank Indonesia akan melakukan transaksi devisa dengan bank-bank untuk keperluan squaring, sedangkan intervensi dilakukan apabila pergerakan nilai tukar telah mendekati, menyentuh, atau melewati batas atas. Untuk tahap awal, target band diumumkan untuk suatu periode waktu yang relatif pendek, misalnya dengan target mingguan, dan selanjutnya dapat diperpanjang tergantung pada perkembangan kondisi pasar yang dihadapi dan kemampuan cadangan devisa yang dimiliki. ${ }^{16}$

Tentu, keberhasilan sistem ini sangat tergantung pada kemampuan cadangan devisa yang dimiliki untuk melakukan intervensi. Akan tetapi berapa jumlah cada-ngan devisa yang dibutuh-kan sangat tergantung pula pada kondisi pasar. Untuk mengurangi kewajiban in-tervensi yang harus dila-kukan oleh Bank Indonesia, diusulkan untuk menerapkan tindakan "soft control" terhadap transaksi devisa antara Bank Indonesia dengan bankbank, dalam bentuk kewajiban menyampaikan dokumen "underlying tran saction", seperti dokumen ekspor dan impor, yang mendasari terjadinya transaksi pembelian devisa tersebut. Kewajiban ini hanya berlaku untuk keperluan "squaring", sedangkan untuk intervensi yang insiatifnya oleh Bank Indonesia tidak diwajibkan. Semua transaksi yang tidak didukung oleh dokumen tidak akan dilayani oleh Bank Indonesia, namun, bank-bank dapat

15 Pada saat menjelang krisis, yaitu sejak bulan Juni sampai dengan Agustus 1997, dilakukan 3 kali pelebaran band untuk mengakomodir tekanan yang cukup berat pada nilai tukar rupiah.

16 Barangkali, muncul pertanyaan kenapa tidak kembali saja ke sistem nilai tukar tetap yang telah terbukti berhasil dipertahankan selama kurang lebih 7 tahun, dari 1971 sampai dengan tahun 1978, dengan segala konsekwensinya. Jawabannya adalah sulit, karena situasi pada masa itu berbeda dengan situasi yang terjadi pada saat ini. Pada periode tersebut, boleh dikatakan, keadaan ekonomi lagi bertumbuh pesat sejalan dengan adanya penerimaan devisa yang cukup besar dari hasil minyak bumi. Dan yang lebih penting lagi, kepercayaan kepada Pemerintah masih cukup kuat. Dewasa ini, krisis ekonomi yang terjadi juga diperberat dengan krisis kepercayaan kepada Pemerintah, sehingga dengan cadangan devisa yang relatif terbatas, sulit diharapkan berhasilnya sistem nilai tukar tetap, kecuali dilakukan kontrol devisa yang sangat ketat. Akan tetapi, kontrol devisa seperti ini tampaknya tidak mungkin dilakukan, karena bukan saja bertentangan dengan dogma-dogma IMF yang mempercayai mekanisme pasar, tetapi merupakan langkah mundur terhadap suatu sistem yang telah berhasil dipertahankan selama hampir tiga dekade. 


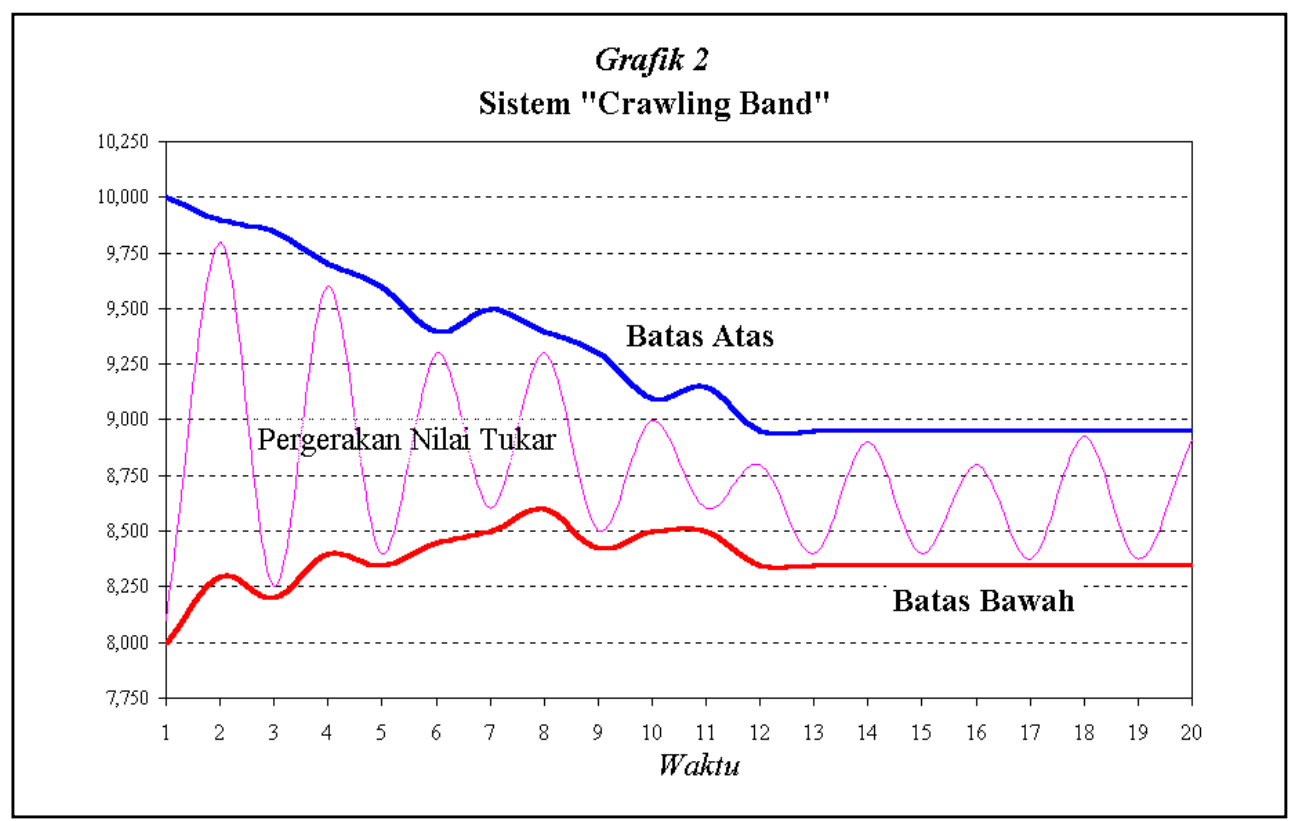

memanfaatkan pasar uang antarbank. Dengan sistem seperti ini, diharapkan transaksi devisa untuk keperluan spekulasi dapat dikurangi, sehingga dampak gejolak transaksi devisa terhadap perubahan nilai tukar dapat diminimalisir. "Soft control ini" dimaksudkan hanya bersifat sementara sampai kondisi moneter normal kembali. ${ }^{17}$

Pihak yang tidak setuju dengan alternatif ini akan meragukan kemampuan Bank Indonesia untuk mempertahankan target band yang diumumkan, dan apabila tidak dapat dipertahankan, hal ini akan menurunkan kredibilitas Bank Indonesia yang sedang dipertanyakan dewasa ini. Untukmengantisipasi hal tersebut, padatahap awal Bank Indonesia perlu melakukan pendekatan terhadap pelaku pasar uang dalam negeri yang relatif besar yang jumlahnyatidak banyak.

\subsection{Sistem Koordinasi Transaksi Keuangan Pemerintah}

Koordinasi ini mencakup hubungan yang lebih serasi antara Bank Indonesia dengan Departemen Keuangan baik sebagai pelaksana transaksi keuangan Pemerintah maupun sebagai pengel ola aset milik negara. Dalam hal yang pertama, dampak moneter dari transaksi

17 Tindakan kontrol devisa dilakukan oleh beberapa negara yang mengalami krisis ekonomi. Malaysia, antara lain, menerapkan kontrol devisa secara ketat yang diikuti oleh penerapan sistem nilai tukar tetap. Korea menerapkan kontrol devisa yang tidak seketat Malaysia tetapi sistem nilai tukarnya dibiarkan mengambang. Namun, dengan "Foreign Exchange Act" yangbaru, Korea akan melonggarkan kembali kontrol devisanya mulai bulan April 1999 (Lihat Chung 1998).

18 Sentralisasi seluruh transaksi penerimaan dan pengeluaran Pemerintah dalam satu rekening pada bank sentral dilakukan di Brazil dan Spanyol (Lihat Carlo Cottarelli 1993, hal.13). 
keuangan pemerintah secara nasional akan tercatat pada mutasi rekening pemerintah pada Bank Indonesia, yang dalam statistik moneter tercermin pada faktor NCG dal am neraca Bank Indonesia. Data empiris menunjukkan bahwa perubahan faktor NCG ini sulit diprakirakan, sehingga dalam penyusunan program moneter faktor tersebut diperlakukan secara "arbitrary" yang tentu akan mengurangi efektifitas pencapaian sasaran operasional pengendalian moneter. Untuk mengurangi ketidak pastian perubahan faktor NCG dimaksud, diperlukan koordinasi yang lebih baik antaraBank Indonesia dan Departemen Keuangan, khusunyayang menyangkut “ex-ante" pelaksanaan penerimaan dan pengeluaran Pemerintah.

I dealnya, semua rekening Pemerintah dapat disentralisir di Bank Indonesia sehingga dengan mudah Bank Indonesia dapat memonitor perubahan-perubahan pada NCG secara "ex-post", dan pengaruhnya terhadap perubahan sasaran operasional pengendalian moneter dapat diketahui secara tepat. ${ }^{18}$ A kan tetapi, karena keterbatasan pelayanan Bank Indonesia yang tidak dapat menjangkau semua daerah, dan juga alasan operasional maka dibutuhkan bank-bank persepsi dimana Pemerintah mempunyai rekening yang sifatnyatransitory. Namun, apabila posisi rekening Pemerintah pada bank-bank jumlahnya besar dan fluktuatif, hal ini bukan hanya mengganggu pencapaian target moneter yang ingin dicapai, tetapi juga merupakan doubletaxation terhadap uang publik yang diperoleh dari pajak. Hasil pajak yang dipungut oleh Pemerintah dan kemudian ol eh Departemen dan Lembaga Pemerintah tertentu didepositokan pada bank-bank dan mendapat bunga merupakan tindakan yang tidak fair.

Konkrit usulan adalah, yang pertama, dana milik Pemerintah yang ada pada bankbank haruslah seminimal mungkin dan ditetapkan suatu cap. Agar sistem ini jalan, dapat diciptakan suatu sistem komputer yang bersifat on-line antara bank Indonesia dan bankbank persepsi yang dapat menolak transaksi yang melanggar cap. Kedua, semua deposito milik Departemen dan Lembaga N egara tertentu harus dialihkan kerekening Kas N egara. Ketiga, setiap tindakan Pemerintah yang menyebabkan dampak moneter yang cukup berarti harus terlebih dahulu dikonsultasikan dengan Bank Indonesia.

\subsection{Sistem Pengaturan Resiko Kegagalan Setelmen Antarbank}

Peninjauan kembali pemberian fasilitas overdraft yang sifatnya otomatis dan bahkan tanpajaminan yang memadai. Prinsipnya adalah mengembalikan peranan Bank Indonesia sebagai the len der of last resort pada proporsinya, melalui penerapan suatu mekanisme dan aturan sistem pembayaran yang memadai. ${ }^{19}$ Dalam kaitan ini, perlu ada suatu pengaturan kegagalan setel men antara peserta kliring, sehingga setiap resiko kegagal an setelmen yang

19 Sistem pembayaran yang terbelakang (tidak efisien, lambat dan resiko tinggi) tidak mendukung efektivitas pelaksanaan pengendalian moneter karena peranan suku bunga dalam alokasi dana tidak optimal. (Diskusi lebih lanjut mengenai hal ini, lihat Balino, Dhawan, dan Sundararajan 1994). 
selama ini diambil alih oleh Bank Indonesia dapat dikembalikan kepada bank-bank. Peranan Bank Indonesia sebagai "the lender of last resort" perlu ada batasnya dan jelas kriterianya.

Pengaturan kegagal an setelmen yang realistis dan praktis sebaiknya menggunakan kerangkasurvivors pays yang berarti bahwa bank-bank pesertakliring yang telah mengambil manfaat dari kliring harus pula ikut menanggung resiko kegagalan setelmen yang mungkin timbul. Dalam kaitan ini, prosedur setelmen harus dilakukan dengan cepat dan jelas dalam hitungan jam, bukan hitungan hari. Pola perhitungan kontribusi dari para peserta kliring untuk menutupi posisi bank yang gagal memenuhi kewajiban setelmennya dengan menggunakan formula loss-sharing, dengan prinsip bahwa jumlah kontribusi dari setiap bank peserta adalah proporsional terhadap penggunaan dari pelayanan kliring selama periodetertentu. ${ }^{20}$ Keuntungan dari penerapan prinsip loss-sharing ini tidak membutuhkan sejumlah dana tertentu yang harus disediakan terlebih dahulu. Dalam hal terdapat sejumlah bank mengalami kegagalan sekaligus pada hari yang sama, kliring untuk hari tersebut dapat dibatalkan, atau Bank Indonesia sebagai the lender of last resort memberikan bantuan likuiditas dengan batasan dan persyaratan yang ketat. Prinsipnya, bantuan likuiditas hanya diberikan kepada bank-bank yang mengalami kegagalan setelmen yang berasal dari liquidity risk yang sifatnya sementara, bukan credit risk yang disebabkan insolvency dari bank-bank yang bersangkutan. Untuk menghindari terjadinya "moral hazard" di kalangan peserta, perlu pengenaan sanksi-sanksi, yaitu berupa denda bunga (interest charge) diatas rate tertinggi yang terjadi di pasar uang hari itu. Selain itu, bank tersebut untuk sementara tidak diperbolehkan ikut kliring sampai pinjaman yang diperoleh dilunasi. Sementara itu, bankbank yang karena kontribusinya dalam skim "loss-sharing" menyebabkan saldo gironya berada dibawah giro wajib minimum (GWM) tidak dikenakan sanksi.

Sejalan dengan penerapan aturan kegagalan setelmen diatas, penyelenggaraan kliring dan setelmen perlu dilakukan dengan jadwal yang lebih ketat dengan pelaksanaan setel men dilakukan pada hari kerja yang sama..$^{21} \mathrm{H}$ al ini bukan hanya memberikan kepastian dalam sistem pembayaran, akan tetapi mengurangi terjadinya "float" dalam sistem perbankan serta meniadakan praktek "round-tripping" yang disinyalir banyak dilakukan sejumlah bank selama ini. Bila hal ini dilakukan, maka data posisi rekening giro bank-bank secara akurat dan real time, yang sangat dibutuhkan dalam pelaksanaan operasi pasar terbuka, akan dapat diperoleh.

20 Formula loss-sharing yang diusulkan adalah: $\mathrm{Qi}=\mathrm{Qt} \mathrm{x}(\mathrm{Ki} / \mathrm{Kt})$, dimana, $\mathrm{Qi}=$ jumlah kontribusi individual peserta kliring, Qt= jumlah "liquidity short fall" dari bank peserta yang gagal (posisi debet hasil kliring dikurangi jumlah yang bisa ditutup dari pasar uang dan jumlah jaminan atau saldo giro bank pada Bank Indonesia), Ki = Jumlah nilai seluruh warkat yang dikliringkan oleh individu peserta kliring selama periode tertentu, dan $\mathrm{Kt}=$ jumlah Ki dari semua peserta kliring.

21 Dengan beroperasinya sistem kliring elektronik Jakarta, percepatan proses setelmen hasil kliring antarbank akan lebih mudah dilakukan. 


\subsection{O bligasi Pemerintah Sebagai Instrumen Moneter}

Penerbitan obligasi Pemerintah dalam bentuk, katakanlah, "Sertifikat Pemerintah Indonesia (SPI)" sebagai alternatif instrumen moneter selain SBI yang digunakan saat ini. Instrumen SPI ini akan dapat berfungsi dua arah (double-sided), baik untuk kontraksi maupun untuk ekspansi likuiditas. Beban moneter dari sisi bank sentral akan rendah, karena biaya bunga yang timbul akan menjadi beban anggaran pemerintah. Otonomi pengendalian moneter akan dapat diperoleh, karena operasi pasar terbuka dapat dilakukan secara independen tanpa harus memperhatikan pengelolaan utang bank sentral. ${ }^{22}$ Selain bermanfaat sebagai instrumen moneter, SPI berperan sebagai sumber penerimaan bagi anggaran Pemerintah untuk dapat membiayai defisit yang jumlahnya cukup besar, khususnya untuk membiayai program restrukturisasi perbankan yang jumlahnya diperkirakan sangat besar. SPI, khususnya yang berjangka panjang, juga sangat bermanfaat pada pengembangan pasar uang sekunder khususnya pasar sekuritas. Karena tingkat resikonya sangat kecil, kalau tidak boleh dikatakan nol, perubahan-perubahan harga diskonto dari SPI dapat berperan sebagai bench-mark bagi para pelaku baik di pasar sekuritas maupun di pasar uang di dalam negeri.

Tentu akan timbul pertanyaan, apakah penerbitan surat hutang Pemerintah saat ini feasible untuk dilaksanakan? A pakah Pemerintah yang sekarang cukup kredibel untuk melakukan hal dimaksud? Sambil menunggu terbentuknya Pemerintah baru hasil pemilihan umum tahun 1999 yang diharapkan akan mempunyai legitimasi dari rakyat, persiapan penerbitan SPI barangkali sudah dapat digarap. Persiapannya tidak semudah yang dibayangkan karena menyangkut masalah administrasi yang membutuhkan disiplin tinggi. Mekanisme penjualan SPI tersebut barangkali dapat dilakukan kurang lebih seperti lelang SBI yang dilakukan oleh Bank Indonesia sel ama ini. Hal ini masih perlu pengkajian lebih detail, dan barangkali pengal aman negara-negara tetangga dal am hal tersebut perlu dipelajari.

Mengingat SBI selama ini berperan bukan hanyasebagai instrumen kontraksi moneter, tetapi juga sebagai instrumen utama dalam pasar uang dalam negeri, SBI sampai dengan jumlah tertentu masih perlu dipertahankan sehingga tersedia lebih banyak alternatif instrumen pasaruang antarbank untuk penanaman kelebihan likuiditasbank-bankjangka pendek.

\section{Penutup}

Sistem pengendalian moneter secara tidak langsung dengan sistem keuangan yang parah yang disertai dengan tekanan faktor eksternal yang cukup berat pada masa krisissaat

22 Hali ini akan terjadi dengan asumsi bahwa SPI tersebut di jual ke masyarakat atau perbankan, dan intervensi Bank Indonesia dilakukan melalui pasar sekunder. Sisi negatif dari asumsi ini, barangkali, adalah kekhawatiran mengenai dampak "crowding out" nya terhadap kegiatan investasi masyarakat. Hal ini dapat dikurangi melalui kebijakan moneter yang akomodatif. Apabila SPI dijual ke Bank Indonesia maka akan berdampak ekspansi moneter yang sifatnya sangat inflatoir. Ini tentu tidak dikenhendaki. 
ini menghadapi berbagai tantangan berat. Kendala-kendala yang dihadapi dalam pelaksanaan operasi pengendalian moneter secara efisien dan efektif bukan hanya berasal dari faktor-faktor "autonomous" tetapi juga berasal dari "policy factors" yang berada dalam kendali Bank Indonesia. Faktor-faktor autonomous mencakup kondisi sektor keuangan eksternal yang sangat rentan terhadap gejolak di dalam dan di luar negeri. Dengan sistem devisa bebas dan sistem nilai tukar mengambang penuh yang disertai dengan kondisi pasar uang yang tidak kompetitif, pergerakan nilai tukar rupiah yang stabil sulit diperoleh sehingga menyulitkan upaya pengendalian inflasi. Selain itu, dari sisi internal, transaksi keuangan Pemerintah yang cukup berfluktuasi ikut mempengaruhi efektivitas pelaksanaan operasi moneter sehari-hari. Tambahan lagi, A PBN tahun 1998/ 99 yang ditargetkan mengalami defisit sebesar 6.0 persen dari PDB akan menambah beban yang lebih berat dalam upaya stabilisasi moneter.

Kendala dari policy factors merupakan hal yang sulit dihindari karena adanya dua kepentingan yang berbenturan yang diemban oleh Bank Indonesia secara bersama-sama, yaitu memulihkan kepercayaan masyarakat dan dunia internasional terhadap perbankan nasional serta menstabilkan kondisi moneter yang mengalami gejolak yang ditandai dengan pergerakan nilai tukar yang melemah dan berfluktuasi dan ancaman hiperinflasi di dalam negeri. Di satu sisi, sebagai otoritas pengawasan bank, Bank Indonesia bertanggung jawab dalam penyehatan sistem perbankan dan dalam menjamin kelancaran sistem pembayaran antarbank yang merupakan urat nadi operasi perbankan. Tanggung jawab tersebut, antara lain, dijabarkan dalam pemberian bantuan likuiditas kepada bank-bank yang batasan dan kriterianya kurang jelas. Di sisi lain, fasilitas tersebut menjadi kendala besar dalam pelaksanaan pengendalian moneter secara efisien dan efektif.

Usulan-usulan yang diajukan dalam makalah ini difokuskan pada perubahan atau penyempurnaan berbagai sistem yang dapat mengurangi kendala-kendala yang dihadapi dal am pengendalian moneter. Penerapan sistem nilai tukar crawling band dan pemberlakuan soft control terhadap pembelian devisa oleh bank-bank dari Bank Indonesia akan dapat mengurangi tekanan-tekanan pada pergerakan nilai tukar rupiah. Koordinasi yang lebih serasi antara Bank Indonesia dengan Departemen Keuangan dalam hal pelaksanaan transaksi keuangan Pemerintah, pembatasan pemberian fasilitas overdraft melalui penerapan suatu aturan kegagalan setelmen pembayaran antarbank, serta pengenalan obligasi Pemerintah sebagai alternatif instrumen moneter, bila dilakukan dengan segera, akan sangat membantu dalam pelaksanaan pengendalian moneter secara efisien dan efektif. Semua usulan yang disampaikan masih merupakan pemikiran awal, sehingga apabila usulan ini akan dilaksanakan diperlukan pengkajian dan persiapan yang lebih detail. 
Lampiran 1

Perkembangan Indikator Moneter

(\%)

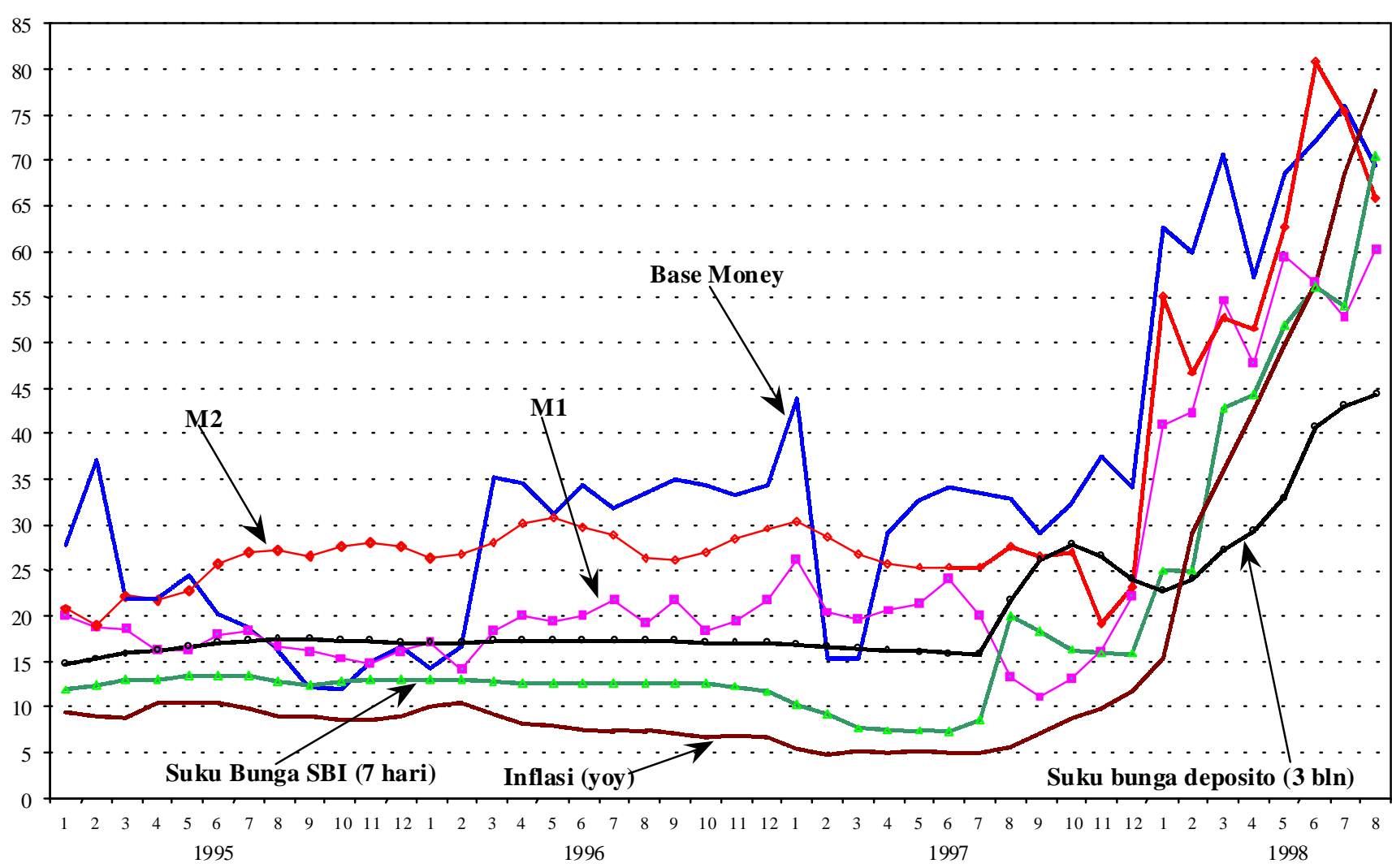


Lampiran 2

Perkembangan Uang Primer dan Faktor-faktor yang Mempengaruhinya (dalam miliar Rp)

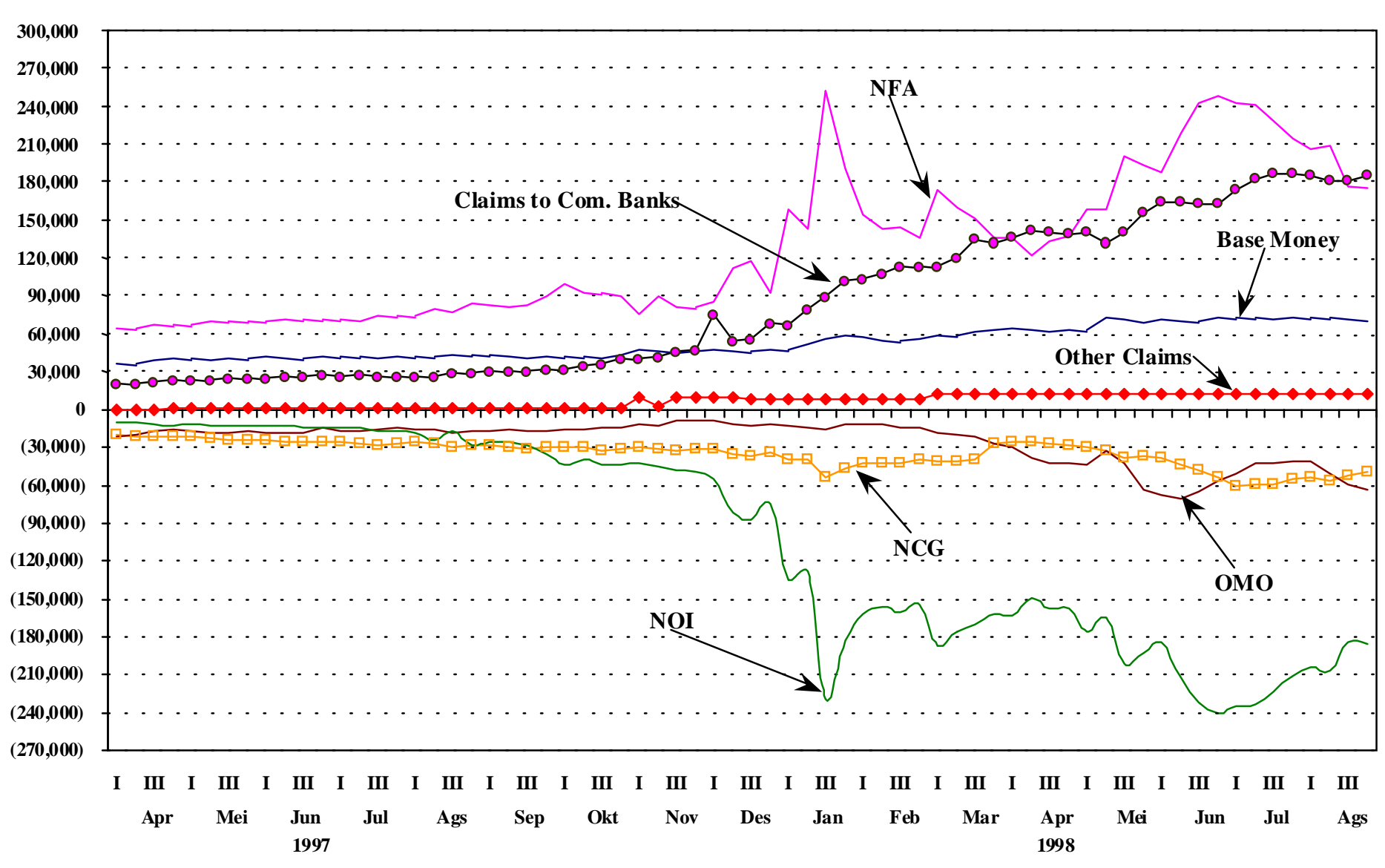




\section{Lampiran 3}

Perkembangan Suku Bunga, NFA dan Nilai Tukar

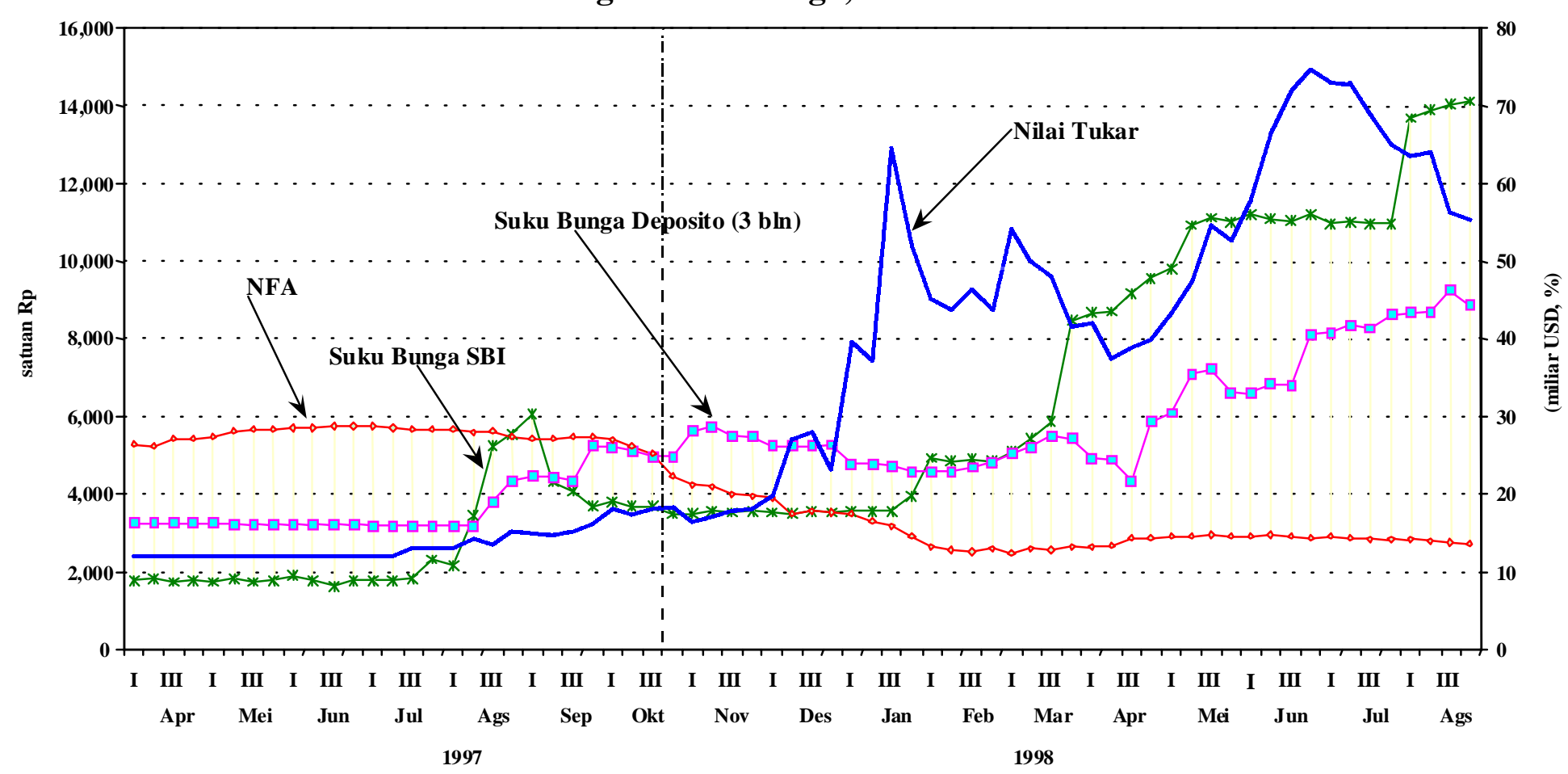




\section{Lampiran 4}

Perkembangan Nilai Tukar Sebelum Kriris

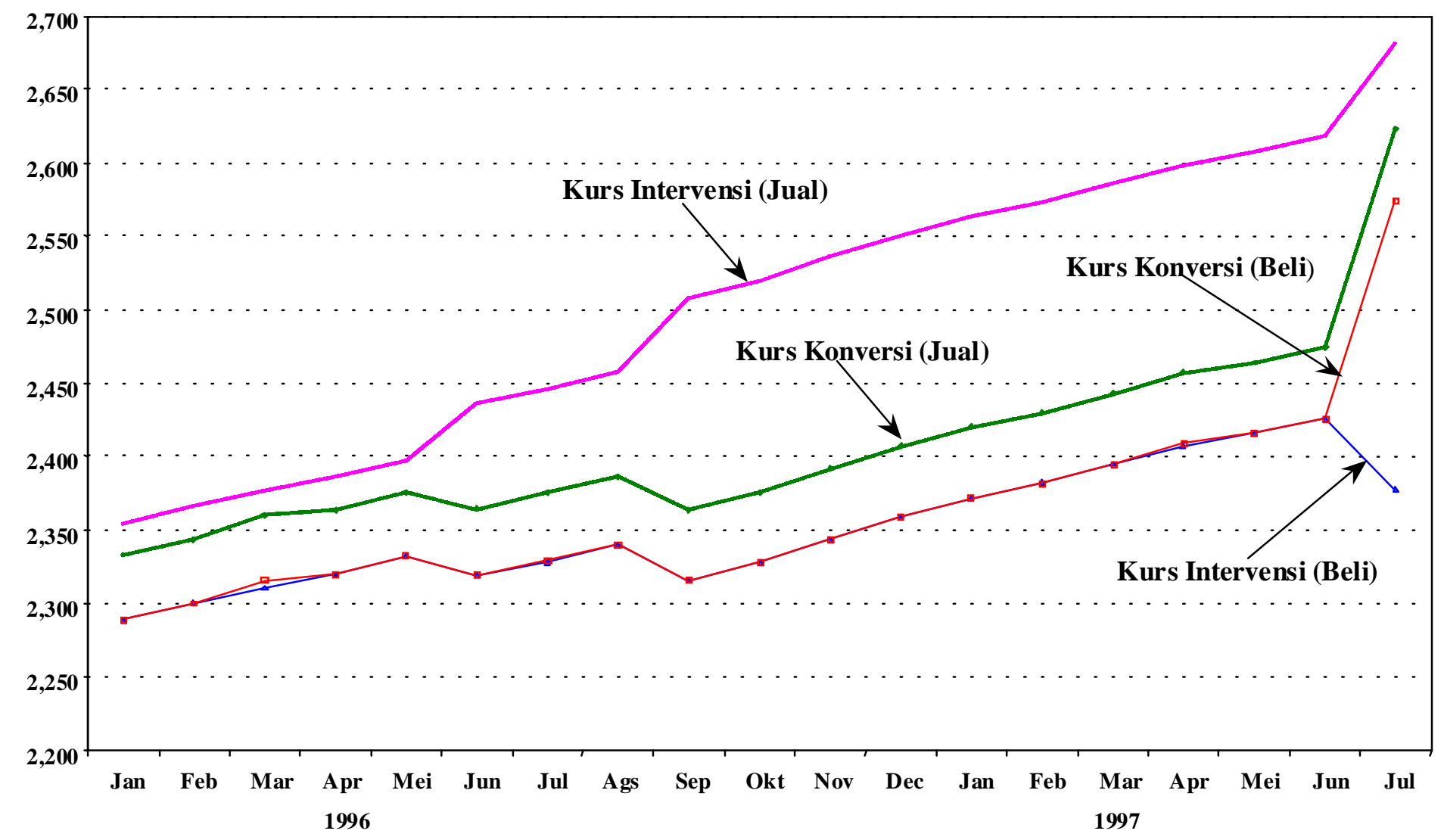

